Prepared in cooperation with the Georgia Environmental Protection Division

\title{
Selected Low-Flow Frequency Statistics for Continuous-Record Streamgages in Georgia, 2013
}

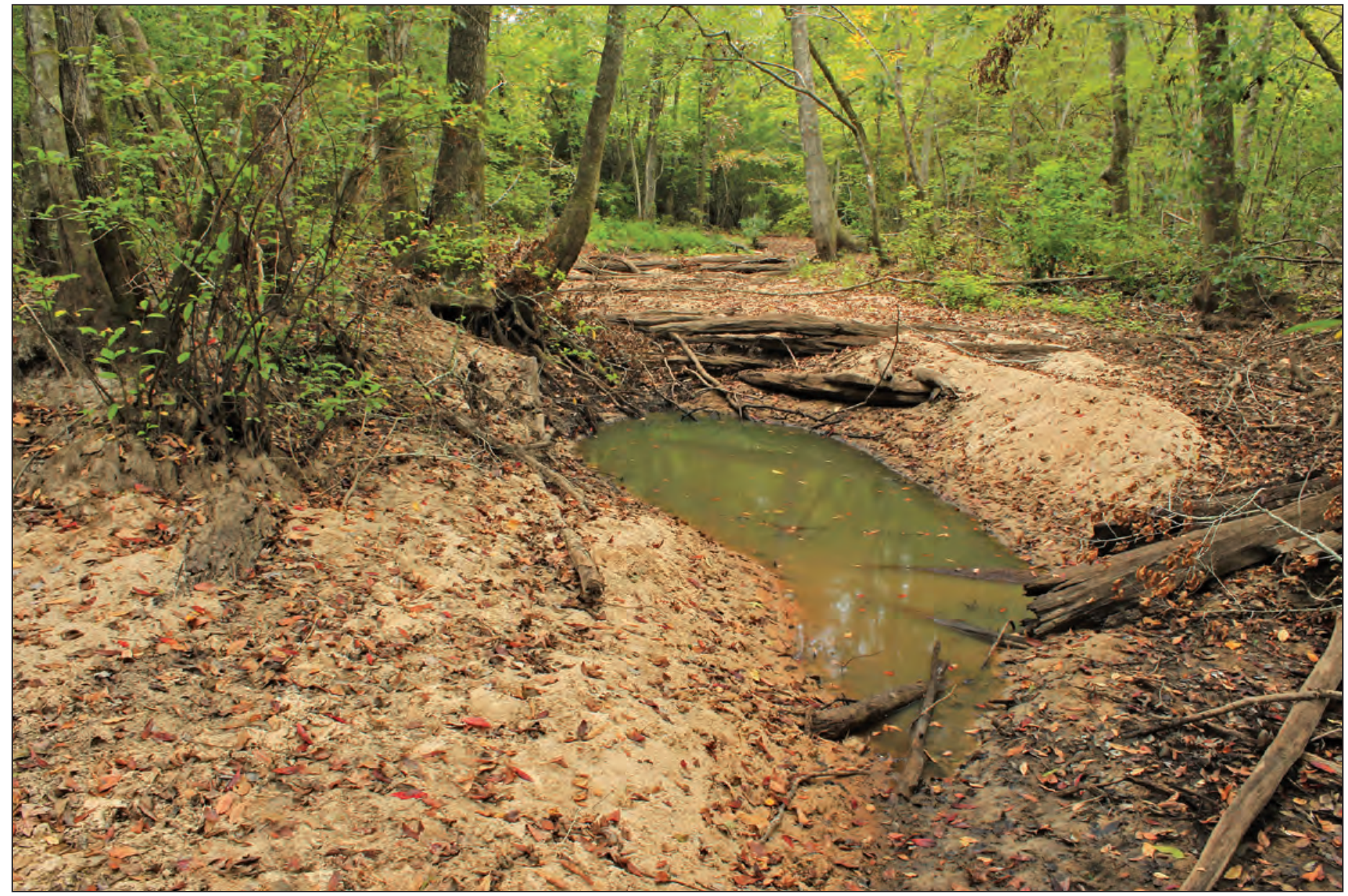

Scientific Investigations Report 2016-5037

U.S. Department of the Interior

U.S. Geological Survey 
Cover. Ichawaynochaway Creek in Randolph County, Georgia, September 22, 2011. Photograph by Alan M. Cressler, U.S. Geological Survey. 


\section{Selected Low-Flow Frequency Statistics for Continuous-Record Streamgages in Georgia, 2013}

By Anthony J. Gotvald

Prepared in cooperation with the Georgia Environmental Protection Division

Scientific Investigations Report 2016-5037 


\title{
U.S. Department of the Interior SALLY JEWELL, Secretary
}

\section{U.S. Geological Survey Suzette M. Kimball, Director}

\author{
U.S. Geological Survey, Reston, Virginia: 2016
}

For more information on the USGS - the Federal source for science about the Earth, its natural and living resources, natural hazards, and the environment—visit http://www.usgs.gov or call 1-888-ASK-USGS.

For an overview of USGS information products, including maps, imagery, and publications, visit http://www.usgs.gov/pubprod/.

Any use of trade, firm, or product names is for descriptive purposes only and does not imply endorsement by the U.S. Government.

Although this information product, for the most part, is in the public domain, it also may contain copyrighted materials as noted in the text. Permission to reproduce copyrighted items must be secured from the copyright owner.

Suggested citation:

Gotvald, A.J., 2016, Selected low-flow frequency statistics for continuous-record streamgages in Georgia, 2013:

U.S. Geological Survey Scientific Investigations Report 2016-5037, 20 p., http://dx.doi.org/10.3133/sir20165037.

ISSN 2328-0328 (online) 


\section{Contents}

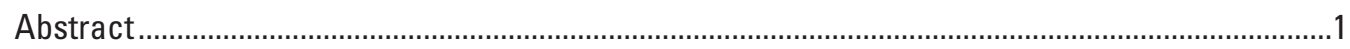

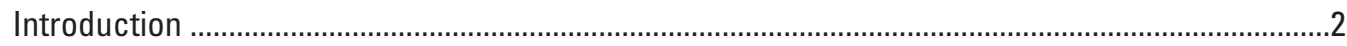

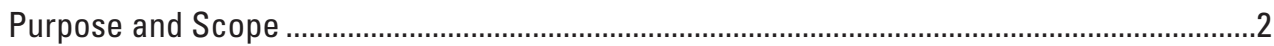

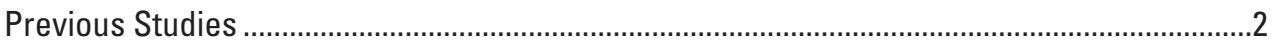

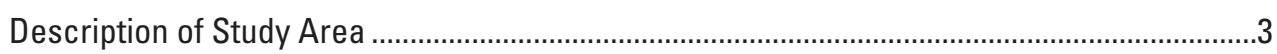

Computation of Low-Flow Frequency Statistics ......................................................................

Statistical Analysis of Trends in Annual and Monthly Minimum N-day Flows................................7

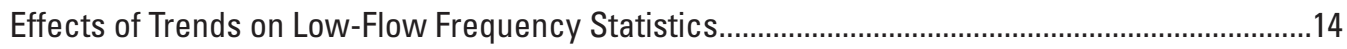

Access to Updated Low-Flow Characteristics Through StreamStats Application ..........................16

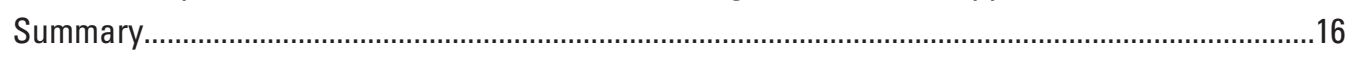

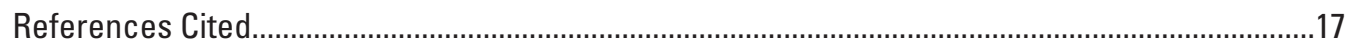

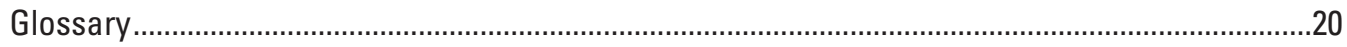




\section{Figures}

1. Map showing location of study area and ecoregions in Georgia ....

2. Graph showing part of an annual hydrograph with the periods of monthly minimum 7-day average flow for January and February for both the daily mean flows bounded by the month and including the daily mean flow for the last 6 days of the previous month.

3. Map showing locations of 197 continuous-record streamgages in Georgia for which low-flow frequency statistics were computed.

4. Maps showing direction and significance of trends in the annual minimum 7-day average flow for unregulated long-term streamgages with current (2013) flow data in Georgia for the entire period of record, climatic years 1964-2013, and climatic years 1944-2013.

5. Graphs showing annual minimum 7-day average flow and Kendall's tau trend for eight long-term streamgages in Georgia....

6. Graphs showing annual average air temperature for northern, central, and southern Georgia

7. Graphs showing annual precipitation totals for northern, central, and southern Georgia

8. Graph showing annual percentage of 1-day precipitation extremes in the southeastern United States

9. Graph showing annual minimum 7-day average flows and 7010 estimates at USGS streamgage 02202500, Ogeechee River near Eden, Georgia

\section{Tables}

[Tables 1, 2, 3, and 5 are available for download at http://dx.doi.org/10.3133/sir20165037]

1. Continuous-record streamgages in Georgia for which low-flow frequency statistics were computed

2. Selected annual and monthly low-flow frequency statistics compiled for 197 continuous-record streamgages in Georgia

3. Results of Kendall's tau statistical test for detection of monotonic trends in select streamflow statistics for the 197 continuous-record streamgages

4. Summary of the number of streamgages with significant positive or negative trends in the annual and monthly minimum 1-day average flows and (or) 7-day average flows......

5. The annual 1010 and 7010 statistics computed on a 10 -year accumulated basis for 39 current (2013) streamgages that indicated a significant trend in the annual minimum 7-day average flow in Georgia

6. Summary of the number of streamgages with an increase or decrease in the annual 7010 statistics from the previous decade. 


\section{Conversion Factors}

Inch/Pound to International System of Units

\begin{tabular}{|c|c|c|}
\hline Multiply & By & To obtain \\
\hline \multicolumn{3}{|c|}{ Length } \\
\hline inch (in.) & 2.54 & centimeter $(\mathrm{cm})$ \\
\hline inch (in.) & 25.4 & millimeter (mm) \\
\hline foot $(\mathrm{ft})$ & 0.3048 & meter $(\mathrm{m})$ \\
\hline \multicolumn{3}{|c|}{ Area } \\
\hline square mile $\left(\mathrm{mi}^{2}\right)$ & 259.0 & hectare (ha) \\
\hline square mile $\left(\mathrm{mi}^{2}\right)$ & 2.590 & square kilometer $\left(\mathrm{km}^{2}\right)$ \\
\hline \multicolumn{3}{|c|}{ Flow rate } \\
\hline cubic foot per second $\left(\mathrm{ft}^{3} / \mathrm{s}\right)$ & 0.02832 & cubic meter per second $\left(\mathrm{m}^{3} / \mathrm{s}\right)$ \\
\hline
\end{tabular}

Temperature in degrees Fahrenheit $\left({ }^{\circ} \mathrm{F}\right)$ may be converted to degrees Celsius $\left({ }^{\circ} \mathrm{C}\right)$ as

${ }^{\circ} \mathrm{C}=\left({ }^{\circ} \mathrm{F}-32\right) / 1.8$.

\section{Datums}

Vertical coordinate information is referenced to the North American Vertical Datum of 1988

(NAVD 88).

Horizontal coordinate information is referenced to the North American Datum of 1927 (NAD 27) or the North American Datum of 1983 (NAD 83) as noted.

Altitude, as used in this report, refers to distance above the vertical datum.

\section{Abbreviations}

1010 minimum 1-day average streamflow with a 10-year recurrence interval

7010 minimum 7-day average streamflow with a 10-year recurrence interval

DNR Department of Natural Resources

EPA U.S. Environmental Protection Agency

EPD Environmental Protection Division

GIS geographic information system

HCDN Hydro-Climatic Data Network

LOWESS locally weighted scatterplot smoothing

NCEI National Centers for Environmental Information

NOAA National Oceanic and Atmospheric Administration

SWSTAT Surface-Water Statistics

USGS U.S. Geological Survey 


\section{Acknowledgments}

The author wishes to thank the many local, State, and Federal agencies that have cooperated in the funding for the operation and maintenance of the gages used in this study. The author also wishes to thank the dedicated work of the USGS field-office staff in collecting, processing, and storing the streamflow data necessary for the completion of this study. 


\title{
Selected Low-Flow Frequency Statistics for Continuous-Record Streamgages in Georgia, 2013
}

\author{
By Anthony J. Gotvald
}

\section{Abstract}

This report presents the annual and monthly minimum 1- and 7-day average streamflows with the 10-year recurrence interval (1Q10 and 7Q10) for 197 continuousrecord streamgages in Georgia. Streamgages used in the study included active and discontinued stations having a minimum of 10 complete climatic years of record as of September 30, 2013. The 1Q10 and 7Q10 flow statistics were computed for 85 streamgages on unregulated streams with minimal diversions upstream, 43 streamgages on regulated streams, and 69 streamgages known, or considered, to be affected by varying degrees of diversions upstream. Descriptive information for each of these streamgages, including the U.S. Geological Survey (USGS) station number, station name, latitude, longitude, county, drainage area, and period of record analyzed also is presented.

Kendall's tau nonparametric test was used to determine the statistical significance of trends in annual and monthly minimum 1-day and 7-day average flows for the 197 streamgages. Significant negative trends in the minimum annual 1-day and 7-day average streamflow were indicated for 77 of the 197 streamgages. Many of these significant negative trends are due to the period of record ending during one of the recent droughts in Georgia, particularly those streamgages with record through the 2013 water year. Long-term unregulated streamgages with 70 or more years of record indicate significant negative trends in the annual minimum 7-day average flow for central and southern Georgia. Watersheds for some of these streamgages have experienced minimal human impact, thus indicating that the significant negative trends observed in flows at the long-term streamgages may be influenced by changing climatological conditions. A Kendall-tau trend analysis of the annual air temperature and precipitation totals for Georgia indicated no significant trends. A comprehensive analysis of causes of the trends in annual and monthly minimum 1-day and 7-day average flows in central and southern Georgia is outside the scope of this study. Further study is needed to determine some of the causes, including both climatological and human impacts, of the significant negative trends in annual minimum 1-day and 7-day average flows in central and southern Georgia.

To assess the changes in the annual 1Q10 and 7Q10 statistics over time for long-term continuous streamgages with significant trends in record, the annual 1Q10 and 7Q10 statistics were computed on a decadal accumulated basis for 39 streamgages having 40 or more years of record that indicated a significant trend. Records from most of the streamgages showed a decline in 7Q10 statistics for the decades of 1980-89, 1990-99, and 2000-09 because of the recent droughts in Georgia. Twenty four of the 39 streamgages had complete records from 1980 to 2010, and records from 23 of these gages exhibited a decline in the 7Q10 statistics during this period, ranging from -6.3 to -76.2 percent with a mean of -27.3 percent. No attempts were made during this study to adjust streamflow records or statistical analyses on the basis of trends.

The monthly and annual 1Q10 and 7Q10 flow statistics for the entire period of record analyzed in the study are incorporated into the USGS StreamStatsDB, which is a database accessible to users through the recently released USGS StreamStats application for Georgia. StreamStats is a Web-based geographic information system that provides users with access to an assortment of analytical tools that are useful for water-resources planning and management, and for engineering design applications, such as the design of bridges. StreamStats allows users to easily obtain streamflow statistics, basin characteristics, and other information for user-selected streamgages. 
Selected Low-Flow Frequency Statistics for Continuous-Record Streamgages in Georgia, 2013

\section{Introduction}

Low-flow frequency statistics for streams are crucial for water-resources planning, management, and permitting to ensure adequate water supply exists for consumptive use, water-quality standards are met, recreation is feasible, and aquatic habitat is minimally impaired. Engineers, scientists, water-resource managers, and many others use low-flow frequency statistics for (1) establishing minimum flow requirements for streams and rivers, (2) quantifying base flows in streams and rivers, (3) wastewater discharge permitting, (4) water-supply planning and management, (5) protecting stream biota and ecosystems, and (6) evaluating time of travel and dilution of toxic spills (Ries, 2006). Recent droughts in the southeastern United States also have emphasized the need to better understand low-flow frequency statistics for sustained water supplies and the ecological-flow requirements for the protection of aquatic resources in Georgia.

Low-flow frequency statistics are computed for a U.S. Geological Survey (USGS) streamgage ${ }^{1}$ using continuous record of daily streamflow (or "flow"; terms are used interchangeably herein). Because the low-flow frequency statistics for streamgages use a finite record length and time period, the statistics should be considered estimates when used to predict long-term and future low-flow conditions. Statistics also change over time as longer streamflow records become available for streamgages, and as extreme hydrologic conditions, such as droughts, influence the computed statistics. As a result, low-flow frequency statistics should be updated periodically to reflect the longer record lengths available for the streamgages (Ries, 2006).

The Georgia Environmental Protection Division (EPD) within the Department of Natural Resources (DNR) uses lowflow frequency statistics in its mission to provide the strategic information necessary to manage the State's water resources and to assess the streamflow needed to maintain ecological integrity in surface waters. The EPD also uses low-flow statistics in its mission to protect and enhance Georgia's surface-water and groundwater resources. In 2014, the USGS, in cooperation with the Georgia EPD, updated selected low-flow statistics at selected continuous-record streamgages in Georgia.

Low-flow frequency statistics provided in this report support USGS priority water-resource issues at both the national and water-science-center levels. This study addresses the natural hazards strategic action under the long-term mission goals of the USGS to enhance understanding of the linkages among natural hazards, the environment, climate, and society, and the ways by which climate variability and change influence the frequency and intensity of natural-hazard events (U.S. Geological Survey, 2007). The study also addresses one of the USGS Cooperative Water Program priorities for fiscal year 2014 (U.S. Geological Survey, 2013), namely to support data-collection activities and to establish comprehensive, uniform, and accurate data on surface water, groundwater, water quality, sediment, and water use.

\section{Purpose and Scope}

The purpose of this report is to present selected annual and monthly low-flow frequency statistics for 197 continuousrecord streamgages in Georgia having 10 or more complete climatic years (April 1 through March 31) of streamflow record. Daily mean streamflow records available through the 2013 water year at active and discontinued streamgages in Georgia were included. The report (1) describes the general statistical methods used to compute the annual and monthly low-flow frequency statistics for the streamgages in Georgia; (2) describes the methods used to access monotonic trends in streamflow; (3) presents the annual low-flow frequency statistics for the minimum 1- and 7-day average streamflow with the 10-year recurrence interval (1Q10 and 7Q10); (4) presents the monthly $1 \mathrm{Q} 10$ and 7Q10 statistics; (5) presents the results of the monotonic trend analysis of the minimum 1-day and 7-day average flows; and (6) provides links to the updated information available online through the USGS StreamStats application for Georgia. The areal scope of the study includes the State of Georgia. Use of the 2013 water-year data resulted in streamflow record through September 30,2013, being used to determine the updated annual and monthly low-flow frequency statistics.

\section{Previous Studies}

The earliest low-flow frequency study by the USGS in Georgia was completed by Thomson and Carter (1963), who assessed the impacts of the 1954 drought on streamflow and described graphical regression methods for estimating lowflow frequency statistics. Carter (1977) developed low-flow profiles for the upper stem of the Flint River Basin using streamflow data from seven continuous-record streamgages and miscellaneous base-flow measurements that were made at various locations along the stream. Carter and Putnam (1978) presented annual low-flow frequency statistics for 134 continuous-record streamgages and 102 partial-record streamgages in Georgia. Carter and Fanning (1982) presented monthly low-flow frequency statistics for 129 selected streamgages in Georgia. Carter (1983) assessed the impacts of the 1980-81 drought on streamflow in Georgia. Carter and others (1986), Carter and others (1988a, b, c, d), and Carter and others (1989a, b) developed 7Q10-flow profiles for selected streams in Georgia. These 7Q10-flow profiles incorporated low-flow data from previous USGS reports. Stamey (1996) presented low-flow characteristics for 12 selected streamgages in southwestern Georgia, southeastern Alabama, and northwestern Florida. Stamey (2001) presented low-flow characteristics for 4 selected streamgages located in the Fort Gordon military base in Georgia. Lastly, Stamey (2011) presented an update of the Stamey (1996) study.

${ }^{1}$ Terms shown in bold are defined in the glossary. 


\section{Description of Study Area}

Georgia encompasses 59,425 square miles $\left(\mathrm{mi}^{2}\right)$ in the southeastern United States. Altitudes range from sea level (defined as the North American Vertical Datum of 1988) in coastal areas to 4,784 feet (ft) above sea level at Brasstown Bald in northeast Georgia. Because of its proximity to the warm waters of the Gulf of Mexico and Atlantic Ocean, most of Georgia has warm, humid summers and short, mild winters. In the northern part of the State, however, altitude becomes the more predominant influence with resulting cooler summers and colder, but not severe, winters. Average summer temperatures range from about 72 degrees Fahrenheit $\left({ }^{\circ} \mathrm{F}\right)$ in the northeastern mountains to nearly $82^{\circ} \mathrm{F}$ in parts of southern Georgia. Average winter temperatures range from $39^{\circ} \mathrm{F}$ in the north to about $55^{\circ} \mathrm{F}$ along the lower coast. Average annual precipitation ranges from 45 inches in central and east-central Georgia to 75 inches in the extreme northeastern corner of Georgia (National Oceanic and Atmospheric Administration, 2015a).

Georgia lies within six U.S. Environmental Protection Agency (EPA) level III ecoregions-Southwestern Appalachians, Blue Ridge, Ridge and Valley, Piedmont, Southeastern Plains, and Southern Coastal Plain (fig. 1; U.S. Environmental Protection Agency, 2007). The ecoregions represent areas of general similarity in ecosystems and in the type, quality, and quantity of environmental resources. The ecoregions provide a spatial framework for the research, assessment, management, and monitoring of ecosystems and ecosystem components. The ecoregions were determined from an analysis of the spatial patterns and the composition of biotic and abiotic phenomena that include geology, physiography, vegetation, climate, soils, land use, wildlife, and hydrology (Griffith and others, 2002). The Fall Line, which is named for the steep fall of rivers as they cross this boundary, separates the higher-altitude Southwestern Appalachians, Blue Ridge, Ridge and Valley, and Piedmont ecoregions from the low-lying Southeastern Plains and Southern Coastal Plain ecoregions. The Fall Line marks the head of navigation on the large rivers and hydroelectric dams are located along it at several places across the State (National Oceanic and Atmospheric Administration, 2015a).

The Southwestern Appalachians ecoregion is composed of open, low mountains. The eastern boundary of this ecoregion, along the more abrupt escarpment where it meets the Ridge and Valley ecoregion, is relatively smooth and only slightly notched by small, eastward-flowing streams. The Ridge and Valley is composed of roughly parallel ridges and valleys of various widths, heights, and geologic materials. Springs and caves are relatively numerous, and present-day forests cover about 50 percent of the ecoregion. The Blue Ridge ecoregion varies from narrow ridges to hilly plateaus to more massive mountainous areas. The mostly forested slopes; high-gradient, cool, clear streams; and rugged terrain overlie primarily metamorphic rocks, with smaller areas of igneous and sedimentary geology.

The Piedmont ecoregion is composed of a transitional area between the mostly mountainous ecoregions of the Appalachians to the northwest and the relatively flat Coastal
Plain to the southeast. The ecoregion is a complex mosaic of metamorphic and igneous rocks of Precambrian and Paleozoic age and contains moderately dissected, irregular plains and some hills. The soils tend to be finer textured in this ecoregion than in coastal plain ecoregions to the south. Once largely cultivated, much of the ecoregion has reverted to pine and hardwood woodlands, with increasing conversion to urban and suburban land cover (Omernik, 1987).

The Southeastern Plains ecoregion is composed of irregular plains made up of a mixture of cropland, pasture, woodland, and forest. The sands, silts, and clays of this ecoregion contrast geologically with the older rocks of the Piedmont ecoregion. Altitudes and relief are greater than in the Southern Coastal Plain but generally are less than in much of the Piedmont. Streams in this area have relatively low gradient and sandy bottoms. The Southern Coastal Plain ecoregion consists of mostly flat plains but is heterogeneous, containing barrier islands, coastal lagoons, marshes, and swampy lowlands along the Gulf and Atlantic coasts. Relative to the Southeastern Plains ecoregion, this ecoregion is lower in altitude, with less relief and wetter soils (Omernik, 1987).

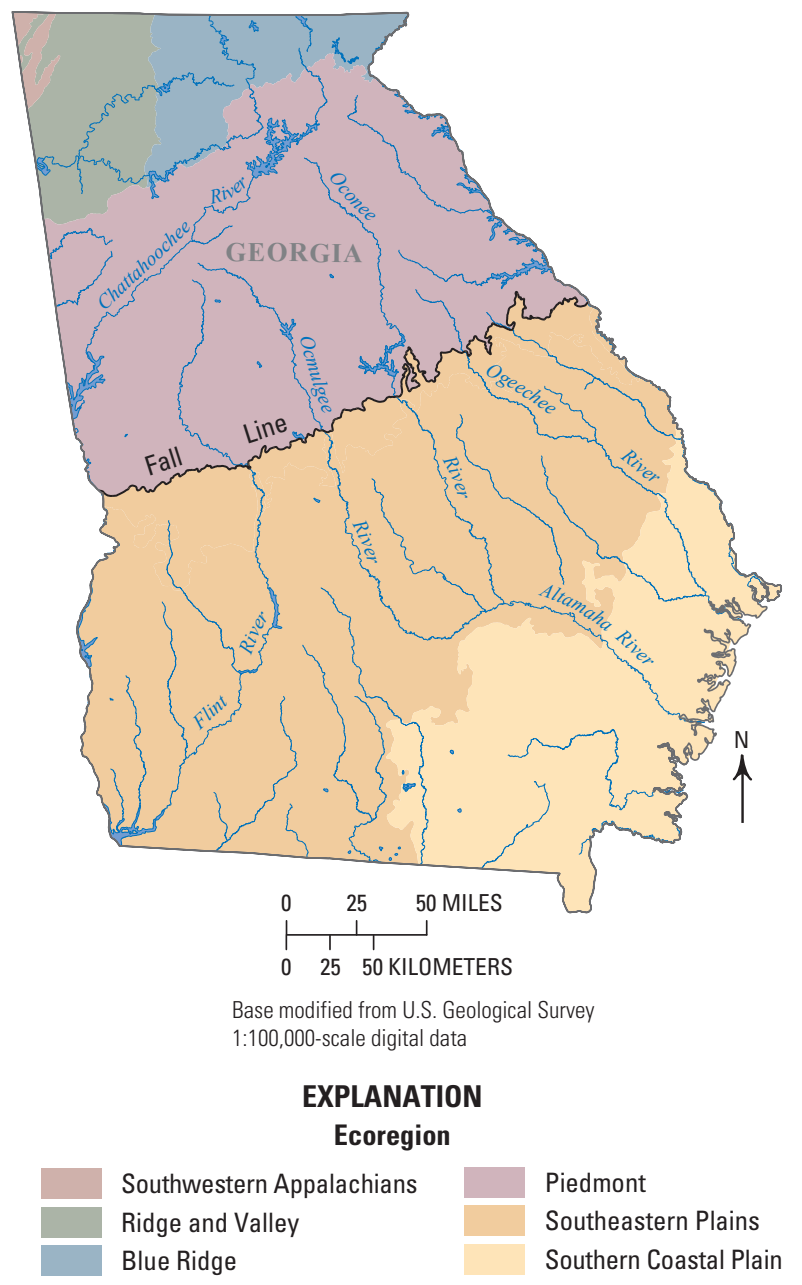

Figure 1. Location of study area and ecoregions in Georgia (ecoregions from U.S. Environmental Protection Agency, 2002; Annals of the Association of American Geographers, 1987). 
Selected Low-Flow Frequency Statistics for Continuous-Record Streamgages in Georgia, 2013

\section{Computation of Low-Flow Frequency Statistics}

Frequency curves relate the magnitude of a variable to the frequency of occurrence (Riggs, 1968). For low-flow frequency studies, the frequency curves relate the minimum average streamflow for a given number of consecutive days (N-day) to the recurrence interval in years (T-year). For example, the minimum 7-day average streamflow with the 10 -year recurrence interval (7Q10) is the minimum average flow for 7 consecutive days, which has a 0.1 probability of not being exceeded in a given year. The recurrence interval is the reciprocal of the probability of recurrence. The recurrence interval also may be defined in general terms as the average interval of time between occurrences of low-flow events (Fowler and Wilson, 2015).

For this study, frequency curves were defined by using a mathematical procedure for fitting the data to a log-Pearson type III distribution (Riggs, 1972). Selected N-day, T-year low-flow statistics can be computed from the following equation:

$$
\log Q_{T}=\bar{X}+K_{T} S
$$

where

$$
\begin{gathered}
Q_{T} \quad \begin{array}{l}
\text { is the minimum N-day average flow for } \\
\text { the T-year recurrence interval, in cubic } \\
\text { feet per second; }
\end{array} \\
\bar{X} \quad \begin{array}{r}
\text { is the mean of the logarithms of the } \\
\text { minimum N-day average flows; }
\end{array} \\
K_{T} \quad \begin{array}{l}
\text { is a frequency factor that is a function } \\
\text { of the recurrence interval and the } \\
\text { coefficient of skew; and }
\end{array} \\
S \quad \begin{array}{l}
\text { is the standard deviation of the logarithms } \\
\text { of the minimum N-day average flows. }
\end{array}
\end{gathered}
$$

When a stream is influenced by flow regulation, the aforementioned techniques for computing low-flow frequency statistics can be applied; however, consistency in the regulation patterns also must be considered. If assessments of the historical streamflow records indicate that the regulation patterns have been relatively consistent and if the logarithm of the annual minimum flows for a given averaging period are consistent with a Pearson Type III distribution, then low-flow statistics can be computed for the regulated station with the understanding that using those statistics for future planning assumes relatively similar regulation patterns will occur in the future (Riggs, 1972; Feaster and Guimaraes, 2014).

The annual and monthly 1 Q10 and 7Q10 statistics for selected streamgages in Georgia were computed using Surface-Water Statistics (SWSTAT) version 5.0, a computer program developed by the USGS (Hutchison, 1975; Lumb and others, 1990; Flynn and others, 1995). The SWSTAT program incorporates standard USGS methods for computing low-flow frequency statistics originally described by Riggs (1972). The annual statistics are based on the climatic year (April 1 through March 31).

The monthly minimum 7-day average flows are typically computed using daily mean flow data that are bounded by month. This approach does not account for the 7-day average flows that occur between months, however, such as the 7-day average flow that occurs from January 26th to February 1st. In some cases, the 7-day average flow between months is less than the minimum 7-day average flow within the month. In order to account for the flows between months, this study incorporates these 7-day average flows into the monthly analysis by including the last 6 days of the previous month for each month's analysis. For example, the January monthly analysis uses the flow data from December 26th to January 31 st. Thus, the running 7-day average flows for January 1st through 6th are included in the monthly analysis and all 7-day average flows throughout the year are used in the monthly analyses. Figure 2 shows an example of the January and February monthly minimum flows computed using the typical approach bounded by the month and also computed using the additional 6 days of flow data from the previous month. In this example, the flows at the beginning and end of the months are lower than the flows in the middle of the month, so the minimum 7-day average flow computed using these flows is smaller than the minimum 7-day average flow bounded by the month.

Streamgages used in the study included both active and discontinued streamgages having a minimum of 10 complete climatic years of record. Ten years of record was selected as the minimum criterion for inclusion of streamgages, because it is widely considered to be the minimum sufficient record length to warrant statistical analysis (Riggs, 1972). Descriptive information for the 197 continuous-record streamgages used in this study, including the USGS station number, station name, latitude, longitude, county, drainage area, and period of record analyzed, are shown in table 1 (available for download at http://dx.doi.org/10.3133/sir20165037); the 197 streamgage locations are shown in figure 3 . The daily mean streamflow data used for this study were retrieved for the 197 streamgages from the USGS National Water Information System (U.S. Geological Survey, 2014). The annual and monthly 1Q10 and 7Q10 statistics for the 197 streamgages are presented in table 2 (available for download at http://dx.doi.org/10.3133/sir20165037), which also includes the mean annual flow for the period of record used in the low-flow frequency analysis. The SWSTAT program does not compute reliable low-flow statistics when skew values exceed an absolute value of 3.3 (Doheny and Banks, 2010). Two 


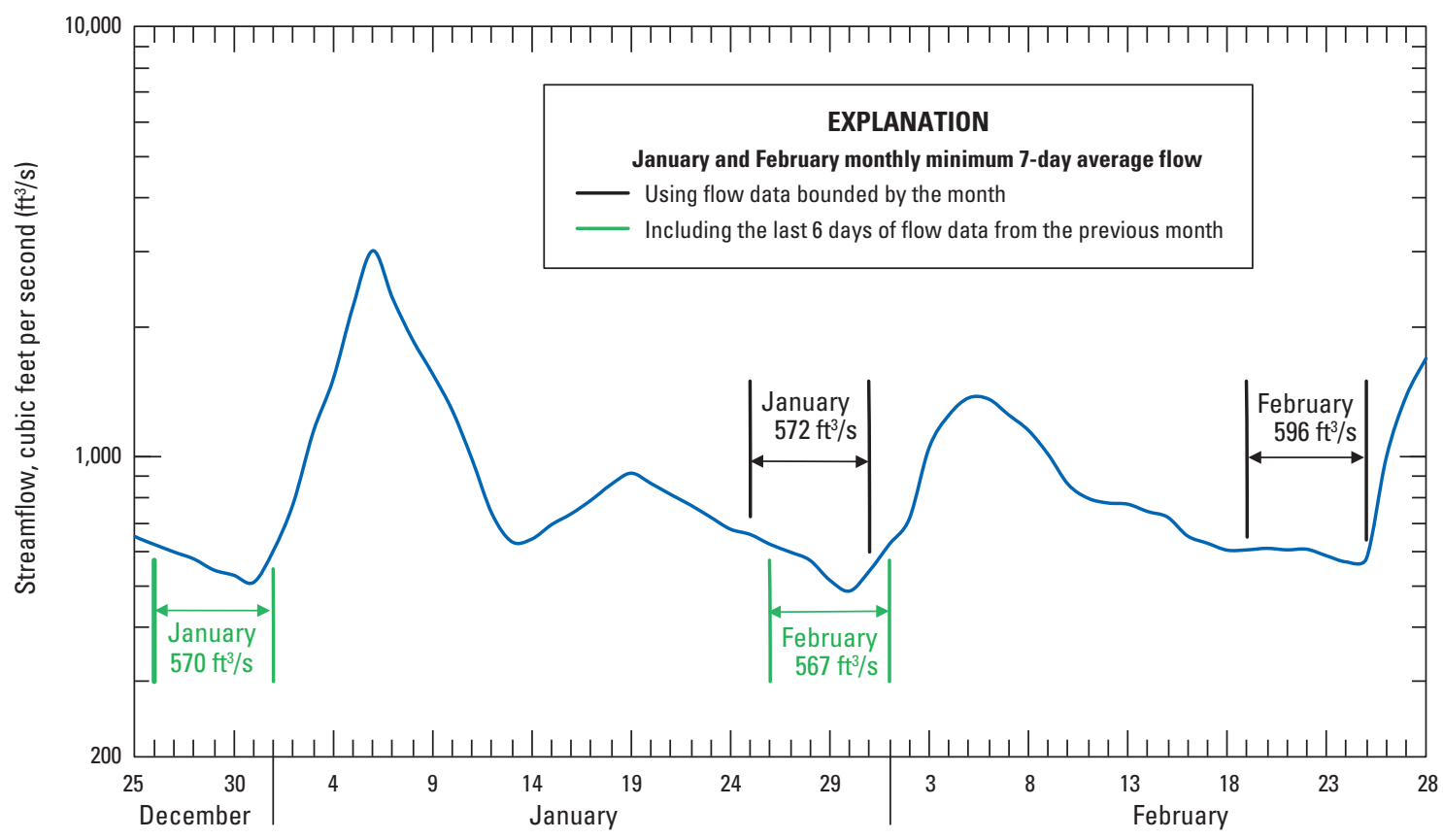

Figure 2. Part of an annual hydrograph with the periods of monthly minimum 7-day average flow for January and February for both the daily mean flows bounded by the month and including the daily mean flow for the last 6 days of the previous month.

streamgages (02181580 and 02357000) have some monthly low-flow frequency curve skews greater than 3.3, so some of the monthly 1Q10 and 7Q10 statistics are not available for these two sites. The statistics that are not available are noted in table 2 .

For those streamgages on regulated streams, low-flow frequency curves are based on the longest period of homogeneous record under current conditions. For this study, the flow patterns at regulated streams were assessed for homogeneity using the quality-assurance and quality-control computer programs described in Feaster and Guimaraes (2014). The streamgages on regulated streams are noted in table 1. Additionally, some investigations have shown that urbanization can lead to a reduction in low flows (U.S. Environmental Protection Agency, 2015). The streamgages in urbanized watersheds for this study are noted in table 1. For this study, a streamgage is considered urbanized if the percentage of impervious area in the respective drainage basin is 10 percent or greater. The percentage of impervious was computed using the 2006 National Land Cover Data (Fry and others, 2011).

Flows at several of the continuous-record streamgages in this study are affected by some form of diversion. Diversions from natural streams occur for various reasons. Some diversions are the result of water-supply withdrawals, manufacturing, point-source discharges, and irrigation. The diversions affect the streamflow regime of a river in various ways and depend not only on where the diversions occur but also on the final outcome of the diverted water. A proper accounting of all diversions in a basin is typically difficult; therefore, most USGS low-flow analyses are made on the data as measured at the streamgage, without adjustments for diversions (Feaster and Guimaraes, 2014). In this study, streamflows were not adjusted for diversions. The streamgages considered to be affected to some degree by upstream diversions are noted in table 1 . 


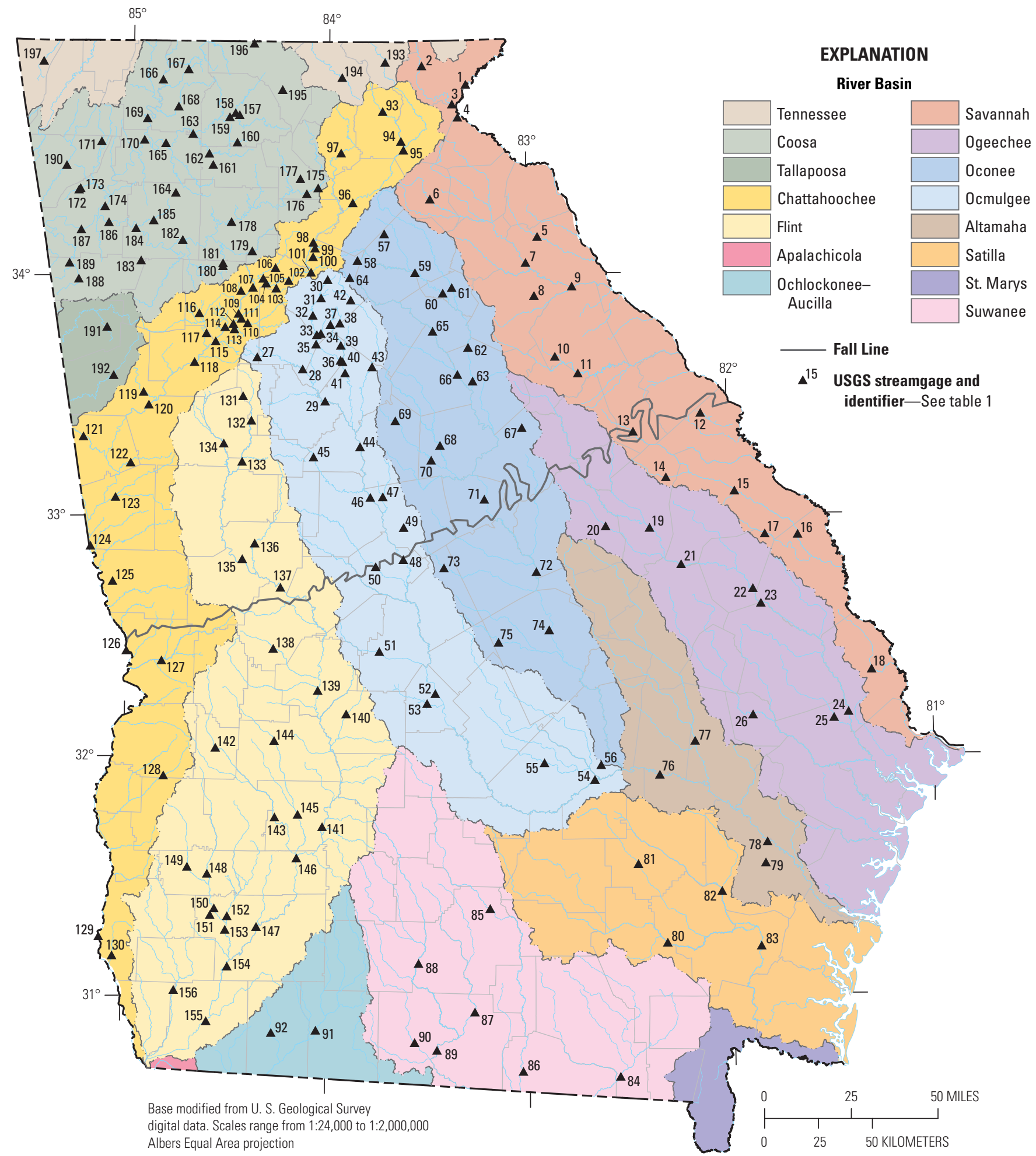

Figure 3. Locations of 197 continuous-record streamgages in Georgia for which low-flow frequency statistics were computed. 


\section{Statistical Analysis of Trends in Annual and Monthly Minimum $\mathbf{N}$-day Flows}

Kendall's tau nonparametric test (Kendall, 1938) was used to determine statistical significance of monotonic trends in annual and monthly minimum 1-day and 7-day average flows with time (Helsel and Hirsch, 1992). A trend was considered statistically significant for a probability value ( $p$-value) less than or equal to $(\leq) 0.05$ that the Kendall's tau value equals zero. Kendall's tau measures the degree of correspondence between two variables (for example, $x$ and $y$ ). For this analysis, the $y$ variable is streamflow and the $x$ variable is time. A concordant pair occurs when both $\mathrm{x}$ and $\mathrm{y}$ variables increase or decrease; a discordant pair occurs when $x$ increases and $y$ decreases or $x$ decreases and $y$ increases. The number of concordant pairs and the number of discordant pairs were tallied for each streamgage and the Kendall's tau value $(\tau)$ was computed using the following equation:

$$
\tau=\frac{C-D}{n(n-1) / 2},
$$

where

$$
\begin{aligned}
C & \text { is the number of concordant pairs; } \\
D & \text { is the number of discordant pairs; and } \\
n & \text { is the sample size. }
\end{aligned}
$$

If the data exhibit perfect positive correlation, then $\tau=1$; if there is perfect negative correlation, then $\tau=-1$; and if there is no correlation between the pairs, then $\tau=0$. Therefore, a positive $\tau$ value is associated with an upward trend and a negative $\tau$ value is associated with a downward trend (Norton and others, 2014). The results of the trend analyses of the annual and monthly minimum 1- and 7-day average flows for the 197 streamgages are shown in table 3 (available for download at http://dx.doi.org/10.3133/sir20165037).

There is an important limitation of the Kendall's tau statistical test when applied to streamflow time-series data that might contain a substantial number of years with no flow for the minimum 1-day and 7-day average flows. The tau and the attendant p-value become highly unreliable, and direct interpretation of their numerical meaning can become tenuous because of ties in the data (Barbie and others, 2012). The trend analysis of minimum 1-day and 7-day average flows for 21 streamgages in this study yield tau and p-values that may be difficult to interpret because of the presence of zero flows. The 21 streamgages with zero flows are noted in table 3 .

Seventy-nine of the 197 streamgages have significant negative trends in the annual minimum 1-day average flows and 89 streamgages have negative trends in the annual minimum 7-day average flows (table 4). In addition, 40 or more of the 197 streamgages have significant negative trends in the monthly minimum 1-day and 7-day average flows for the months of April through November. Multiple droughts have occurred in Georgia since 1998 (Barber and Stamey, 2000; Knaak and Joiner, 2008; Knaak and others, 2009, 2010, 2013; Knaak and Peck, 2014). Most of the streamgages with significant negative trends have a period of record that ends during one of the recent droughts, particularly those streamgages with record through the 2013 climatic year. Far fewer streamgages have significant positive trends, with 11 or fewer of the streamgages having significant positive trends for the annual and monthly 1-day and 7-day flows. Most of these significant positive trends occurred at streamgages with shorter records that had a dry period at the beginning of the record and (or) a wet period at the end of the record.

As noted by Lins and others (2010), sometimes hydrologic records of a few years to a few decades may indicate a trend in the data, but when viewed in the context of longer timeframes spanning decades to centuries, the short-term trends may be recognized as part of a much longer-term oscillation. For hydrologic time-series data, the Kendall test is best suited for analysis of long-term data sets. Although the Kendall test can be applied to short time series, tests applied to short time series may not provide information that is of practical importance. Tests applied to short time series may (1) fail to detect a statistically significant trend even though a large increase or decrease in flow has occurred, or (2) detect a statistically significant trend even though the trend is of no practical importance (Oki, 2004). Thus, long-term streamgaging data are better suited for trend assessments. The USGS uses a cutoff value of 30 years of streamflow record to designate long-term streamgages (U.S. Geological Survey, 2009). For this study, a long-term streamgage is designated as having at least 30 or more years of record.

Trends at long-term unregulated streamgages may result from changes in climatic cycles, land use, changes in upstream diversions for water supply or waste treatment purposes, groundwater pumpage, or other practices that may affect groundwater levels (Weaver, 2015). For regulated streamgages, interpretations of trend analyses are more complex. Streamflows at regulated stations also are influenced by changes in climatic cycles, land use, diversions, and groundwater activities, but those changes can be mitigated, enhanced, or even offset by changes in regulation patterns. Still, trend assessments in the flow patterns are useful to help determine the suitability of a frequency analysis of data collected at a regulated streamgage (Feaster and Guimaraes, 2014).

The USGS Hydro-Climatic Data Network (HCDN) is a subset of all USGS streamgages for which the streamflow primarily reflects prevailing meteorological conditions. These streamgages are screened to exclude streamgages where human activities, such as artificial diversions, storage, and other activities in the drainage basin or the stream channel, affect the natural flow of the watercourse. The purpose of the network is to provide a streamflow data set suitable for analyzing hydrologic variations and trends in a climatic context (Lins, 2012). The Georgia streamgages in the HCDN are noted in table 1 . 
Table 4. Summary of the number of streamgages with significant positive or negative trends in the annual and monthly minimum 1-day average flows and (or) 7-day average flows.

\begin{tabular}{|c|c|c|c|c|}
\hline \multirow{2}{*}{$\begin{array}{l}\text { Streamflow } \\
\text { statistics }\end{array}$} & \multirow{2}{*}{$\begin{array}{c}\text { Minimum } \\
\text { average flow }\end{array}$} & \multicolumn{3}{|c|}{ Number of streamgages } \\
\hline & & $\begin{array}{l}\text { With a significant } \\
\text { negative trend }\end{array}$ & $\begin{array}{l}\text { With a significant } \\
\text { positive trend }\end{array}$ & $\begin{array}{c}\text { With no } \\
\text { significant trent }\end{array}$ \\
\hline \multirow[t]{2}{*}{ Annual } & 1-day & 79 & 10 & 108 \\
\hline & 7-day & 89 & 6 & 102 \\
\hline \multirow[t]{2}{*}{ January } & 1-day & 30 & 4 & 163 \\
\hline & 7-day & 29 & 2 & 166 \\
\hline \multirow[t]{2}{*}{ February } & 1-day & 29 & 4 & 164 \\
\hline & 7-day & 24 & 2 & 171 \\
\hline \multirow[t]{2}{*}{ March } & 1-day & 30 & 3 & 164 \\
\hline & 7-day & 23 & 0 & 174 \\
\hline \multirow[t]{2}{*}{ April } & 1-day & 44 & 4 & 149 \\
\hline & 7-day & 45 & 1 & 151 \\
\hline \multirow[t]{2}{*}{ May } & 1-day & 49 & 10 & 138 \\
\hline & 7-day & 51 & 4 & 142 \\
\hline \multirow[t]{2}{*}{ June } & 1-day & 50 & 10 & 137 \\
\hline & 7-day & 54 & 5 & 138 \\
\hline \multirow[t]{2}{*}{ July } & 1-day & 43 & 9 & 145 \\
\hline & 7-day & 44 & 3 & 150 \\
\hline \multirow[t]{2}{*}{ August } & 1-day & 49 & 8 & 140 \\
\hline & 7-day & 59 & 5 & 133 \\
\hline \multirow[t]{2}{*}{ September } & 1-day & 49 & 10 & 138 \\
\hline & 7-day & 61 & 5 & 131 \\
\hline \multirow[t]{2}{*}{ October } & 1-day & 39 & 10 & 148 \\
\hline & 7-day & 54 & 5 & 138 \\
\hline \multirow[t]{2}{*}{ November } & 1-day & 33 & 11 & 153 \\
\hline & 7-day & 40 & 6 & 151 \\
\hline \multirow[t]{2}{*}{ December } & 1-day & 20 & 11 & 166 \\
\hline & 7-day & 17 & 7 & 173 \\
\hline
\end{tabular}

Data from 31 of the 50 long-term streamgages on unregulated streams that have current (2013) streamflow data indicate a significant negative trend in annual minimum 7-day average flow (fig. 4A). These 31 streamgages, which include 7 HDCN streamgages, are scattered throughout the State. Data from all 20 long-term streamgages on unregulated streams that have complete record during the last 50 years (climatic years 1964-2013), including the HCDN streamgages, show a significant negative trend in annual minimum 7-day average flow (fig. 4B). Looking further back, data from the 17 longterm streamgages on unregulated streams that have complete record for the last 70 years (climatic years 1944-2013) show significant negative trends in central and southern Georgia, but no significant trends in northern Georgia (fig. $4 C$ ). This finding illustrates the importance of using longer record lengths to do trend assessments, because extending the trend analysis from 50 to 70 years resulted in a loss of significance in trends determined for streamgages in north Georgia. 


\section{A. All data}

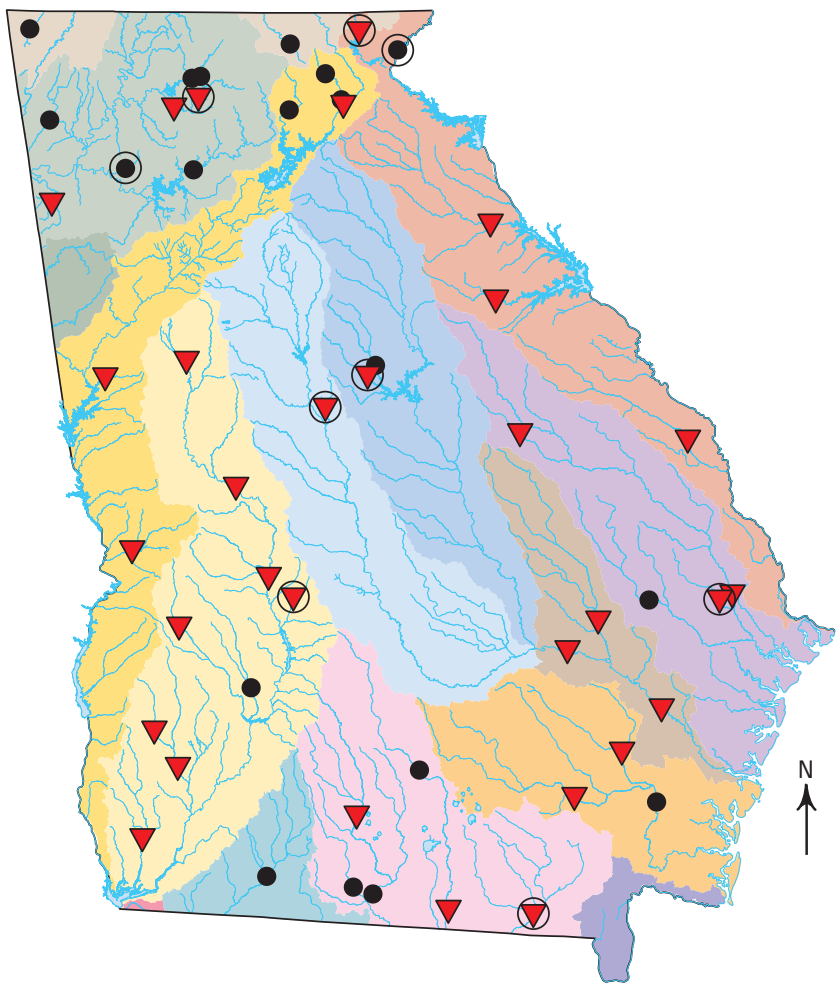

\section{Last 70 years of data}

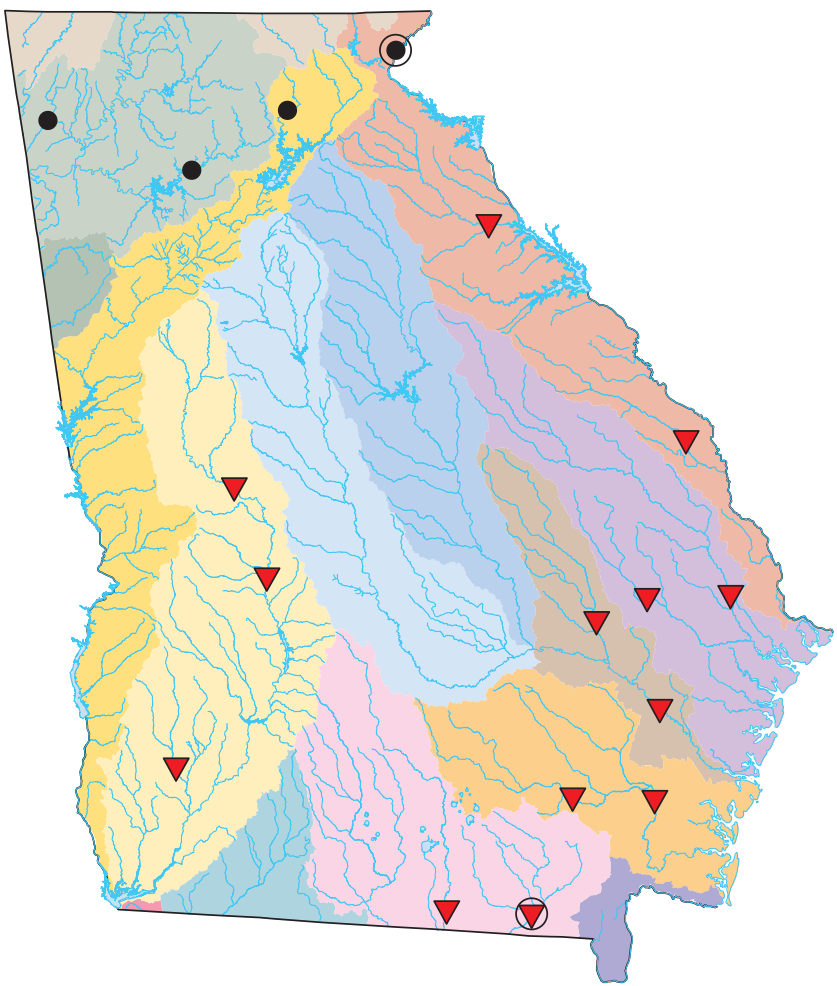

\section{B. Last 50 years of data}

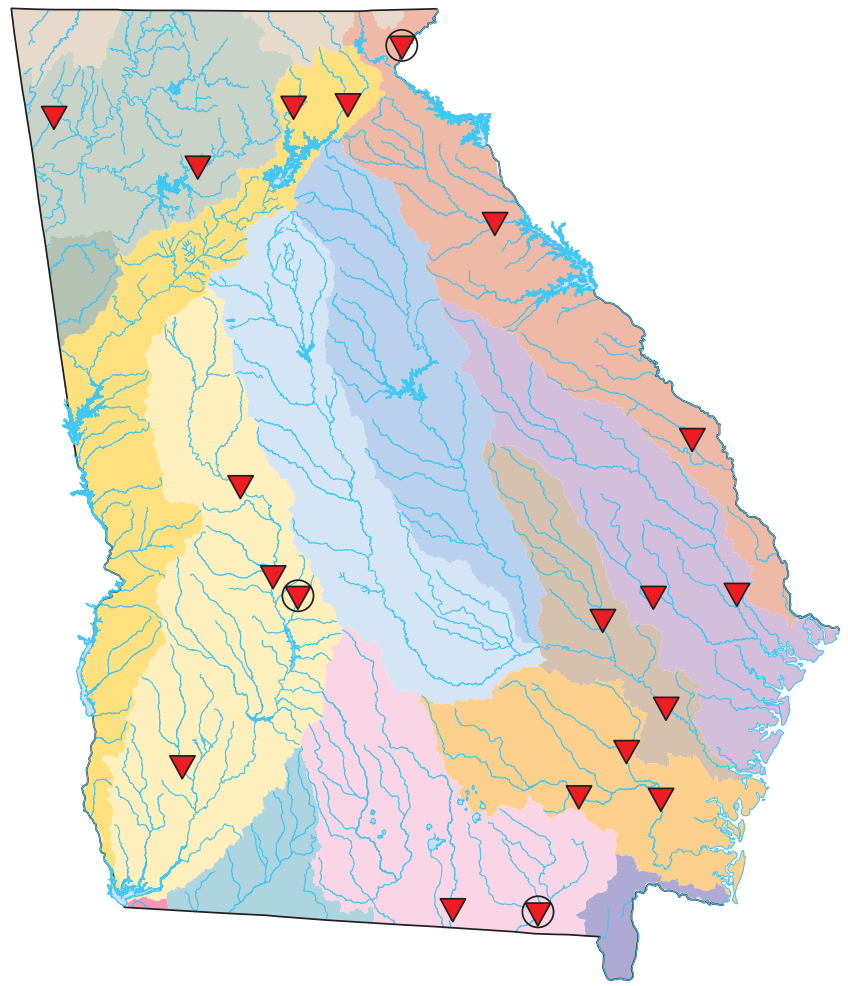

\section{EXPLANATION}

River Basin

\begin{tabular}{|c|c|}
\hline Tennessee & Savannah \\
\hline Coosa & Ogeechee \\
\hline Tallapoosa & Oconee \\
\hline Chattahoochee & Ocmulgee \\
\hline Flint & Altamaha \\
\hline Apalachicola & Satilla \\
\hline Ochlockonee- & St. Marys \\
\hline & Suwanee \\
\hline
\end{tabular}

Trend in annual minimum 7-day average flow-A symbol with a circle indicates a site that is part of the Hydro-Climatic Data Network
$\triangle$ Upward
- O Not significant
$\nabla \otimes$ Downward

Figure 4. Direction and significance of trends in the annual minimum 7-day average flow for unregulated long-term streamgages with current (2013) flow data in Georgia for, $A$, the entire period of record, B, climatic years 1964-2013, and $C$, climatic years 1944-2013. 
Figure 5 shows a plot of the annual minimum 7-day flow for the entire period of record for eight of the current (2013) long-term unregulated streamgages throughout the State having record lengths greater than 70 years. The Kendall-Theil robust line is plotted in figure 5 as an aid for visualizing the trends in the data. The Kendall-Theil robust line is a robust, nonparametric estimate of the slope of a linear trend line relating two variables (Helsel and Hirsch, 1992). The nonparametric estimate of the slope is equal to the median of the slopes between all possible pairs of data. Determination of the statistical significance of the slope of the Kendall-Theil robust line is identical to that of Kendall's tau (Oki, 2004). The eight long-term streamgages all show negative trends throughout the State, but the trends for the two streamgages in northern Georgia are not statistically significant.

Streamflow data from HCDN streamgages in central and southern Georgia show significant negative trends (fig. 4), thus indicating that the significant negative trends spanning over 70 years that are observed in this area may be influenced by changing climatological conditions. To assess the changes in climate in Georgia, a Kendall-tau test was performed on the annual average air temperature data for northern, central, and southern Georgia. The air temperature data were obtained from the National Oceanic and Atmospheric Administration (NOAA) National Centers for Environmental Information (NCEI) Web site (National Oceanic and Atmospheric Administration, 2015b). Figure 6 shows a plot of the annual average air temperature for northern, central, and southern Georgia. The Kendall-tau trend tests did not indicate a significant increase or decrease in annual average air temperature in the three regions of Georgia. As an aid for visualizing any patterns in the data, however, locally weighted scatterplot smoothing (LOWESS) curves are plotted in figure 6. The LOWESS curve is a multivariate smoothing procedure that is applied to time-series data (Cleveland and Devlin, 1988). There appears to be a cyclic pattern in the yearly average air temperatures, with cooler temperatures occurring in the late 1950s through late 1970 s relative to the other periods shown. Additionally, a Kendall-tau trend test was performed on the average air temperature for the three hottest months of the year, June,
July, and August. The Kendall-tau trend tests did not indicate a significant trend in annual average air temperature for any of the three months. A cyclic pattern for these three months is similar to that of the annual data, with cooler temperatures during the late 1950 s to late 1970 s relative to other periods.

A Kendall-tau test was also performed on the annual precipitation data for northern, central, and southern Georgia. The data were obtained from the NOAA NCEI Web site (National Oceanic and Atmospheric Administration, 2015b). Figure 7 shows the annual precipitation totals for northern, central, and southern Georgia. The Kendall-tau trend test did not indicate a significant trend in annual precipitation for the three regions in Georgia. The 1-day precipitation extreme data available from the NOAA NCEI Web site, however, do indicate a significant positive trend in the percentage of 1-day precipitation extremes for the southeastern United States (fig. 8; National Oceanic and Atmospheric Administration, 2015c). A 1-day precipitation extreme is a 1-day precipitation total in the upper tenth percentile for the period of record. Because there is an increasing trend in 1-day precipitation extremes and no increasing trend in annual precipitation totals over time, the increase in 1-day extremes may be offsetting declines in less intense rain events of longer duration, which replenish groundwater and low-flow in the streams. Thus, further detailed analyses of the timing and intensity of precipitation throughout the year is needed to better understand the effects of precipitation patterns on changes in low-flow in the stream.

A comprehensive analysis of the causes of the trends in annual and monthly minimum 1-day and 7-day average flows in central and southern Georgia is outside the scope of this report. Not only is an extensive analysis of the effects of climatic variability or change on low-flows in streams needed, but also a thorough analysis of other factors that affect the low-flow in streams, such as land use, diversions for water supply or waste treatment purposes, irrigation withdrawals, and other groundwater activities. Characterizing trends in streamflow and developing a greater understanding of the causes of trends is critical to understanding future water availability. 

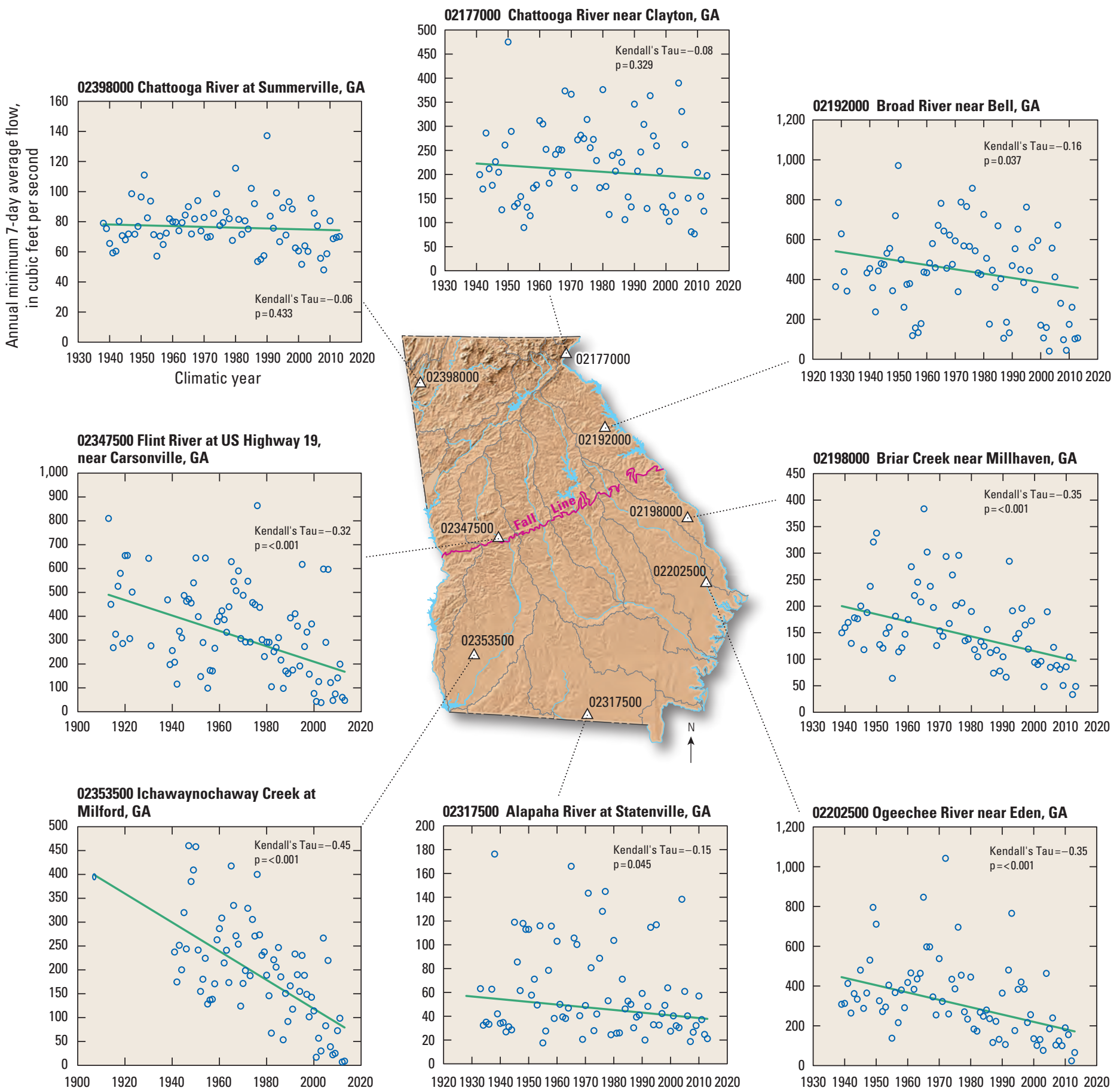

\section{EXPLANATION}

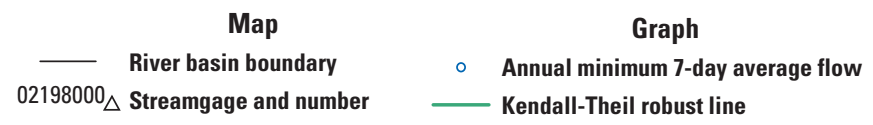

Figure 5. Annual minimum 7-day average flow and Kendall's tau trend for eight long-term streamgages in Georgia. 


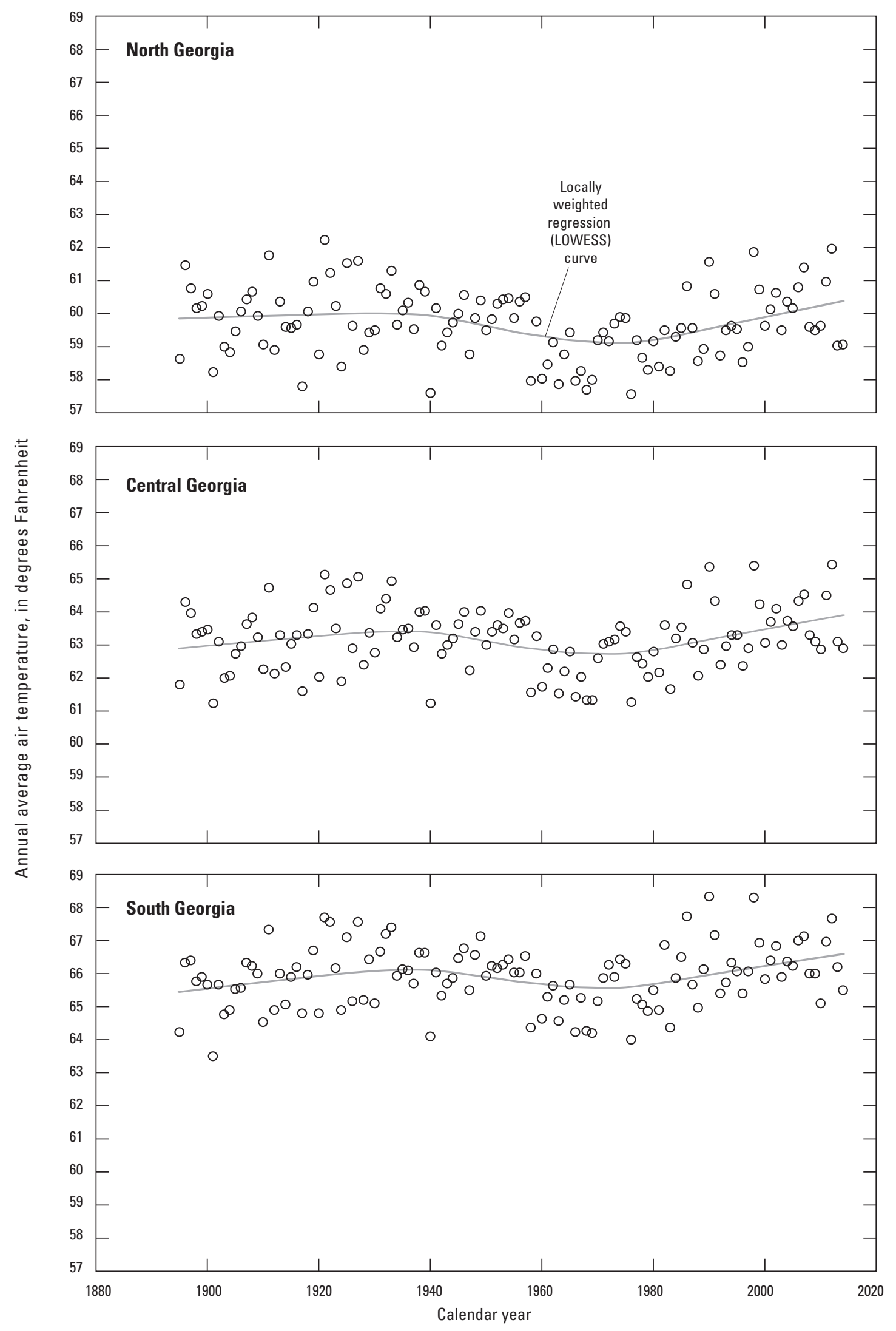

Figure 6. Annual average air temperature for northern, central, and southern Georgia (data from the National Oceanic and Atmospheric Administration, 2015b). 

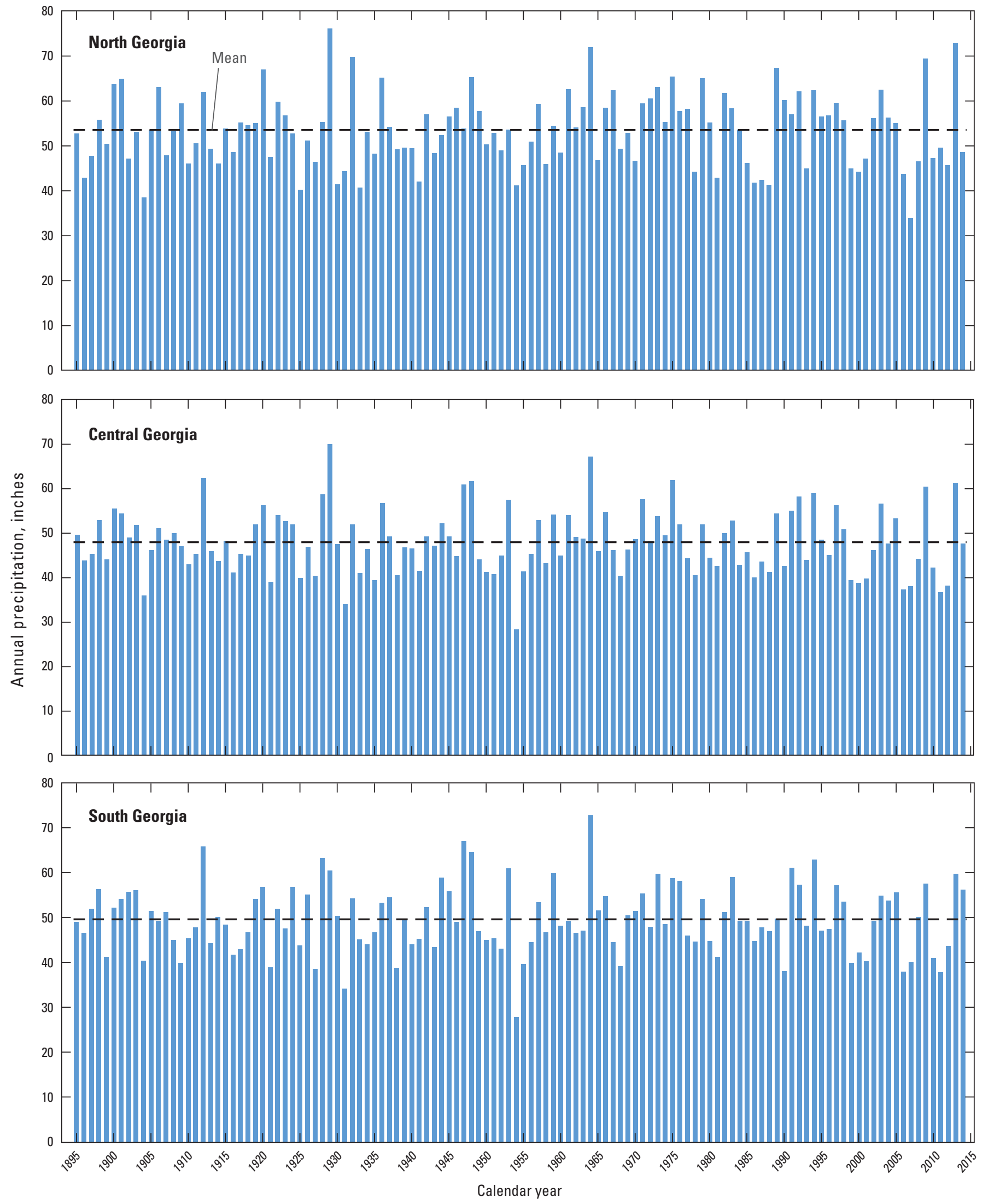

Figure 7. Annual precipitation totals for northern, central, and southern Georgia (data from the National Oceanic and Atmospheric Administration, 2015b). 


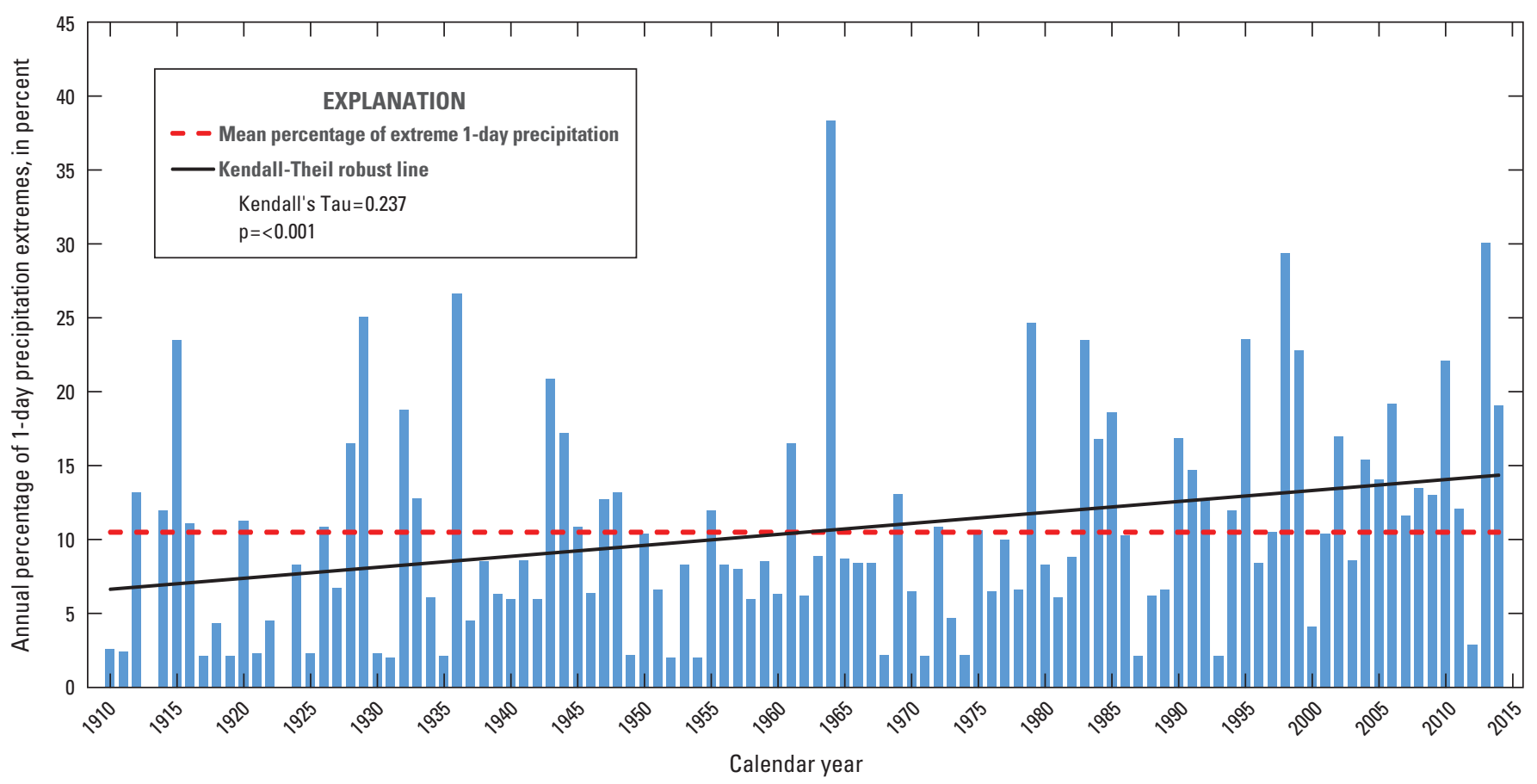

Figure 8. Annual percentage of 1-day precipitation extremes in the southeastern United States (data from the National Oceanic and Atmospheric Administration, 2015c).

\section{Effects of Trends on Low-Flow Frequency Statistics}

Trends in the minimum N-day average flow can affect the low-flow frequency statistics for a continuous-record streamgage. To illustrate the effect of a significant negative trend in annual minimum 7-day average flow on annual 7Q10 flow, the annual 7Q10 for USGS streamgage 02202500, Ogeechee River near Eden, GA, was computed beginning with the first 10 years of record (April 1938-March 1948) and then computed on a 5-year accumulated basis through climatic year 2011. Figure 9 shows the annual minimum 7-day average flow by climatic year, along with the computed annual 7Q10. By climatic year 1978, the annual 7Q10 was 239 cubic feet per second $\left(\mathrm{ft}^{3} / \mathrm{s}\right)$, which is close to the annual 7Q10 value of $240 \mathrm{ft}^{3} / \mathrm{s}$ computed by Carter and Putnam (1978) for this streamgage. After 1978, the annual 7Q10 decreased every 5 years and was $141 \mathrm{ft}^{3} / \mathrm{s}$ using record from April 1938 to March 2011.

To assess the changes in the annual $1 \mathrm{Q} 10$ and 7Q10 statistics over time for long-term streamgages with significant trends in record, the annual 1Q10 and 7Q10 statistics were computed on a decadal accumulated basis for the current (2013) streamgages with 40 or more years of record that indicated a significant trend in the annual minimum 7-day average flow. In this study, 39 continuous-record streamgages fit these criteria, and statistics for all 39 streamgages indicated a significant negative trend. Table 5 (available for download at http://dx.doi.org/10.3133/sir20165037) shows the annual 1Q10 and 7Q10 statistics for the 39 long-term streamgages at the beginning of each decade from 1960 to 2010 . The annual 


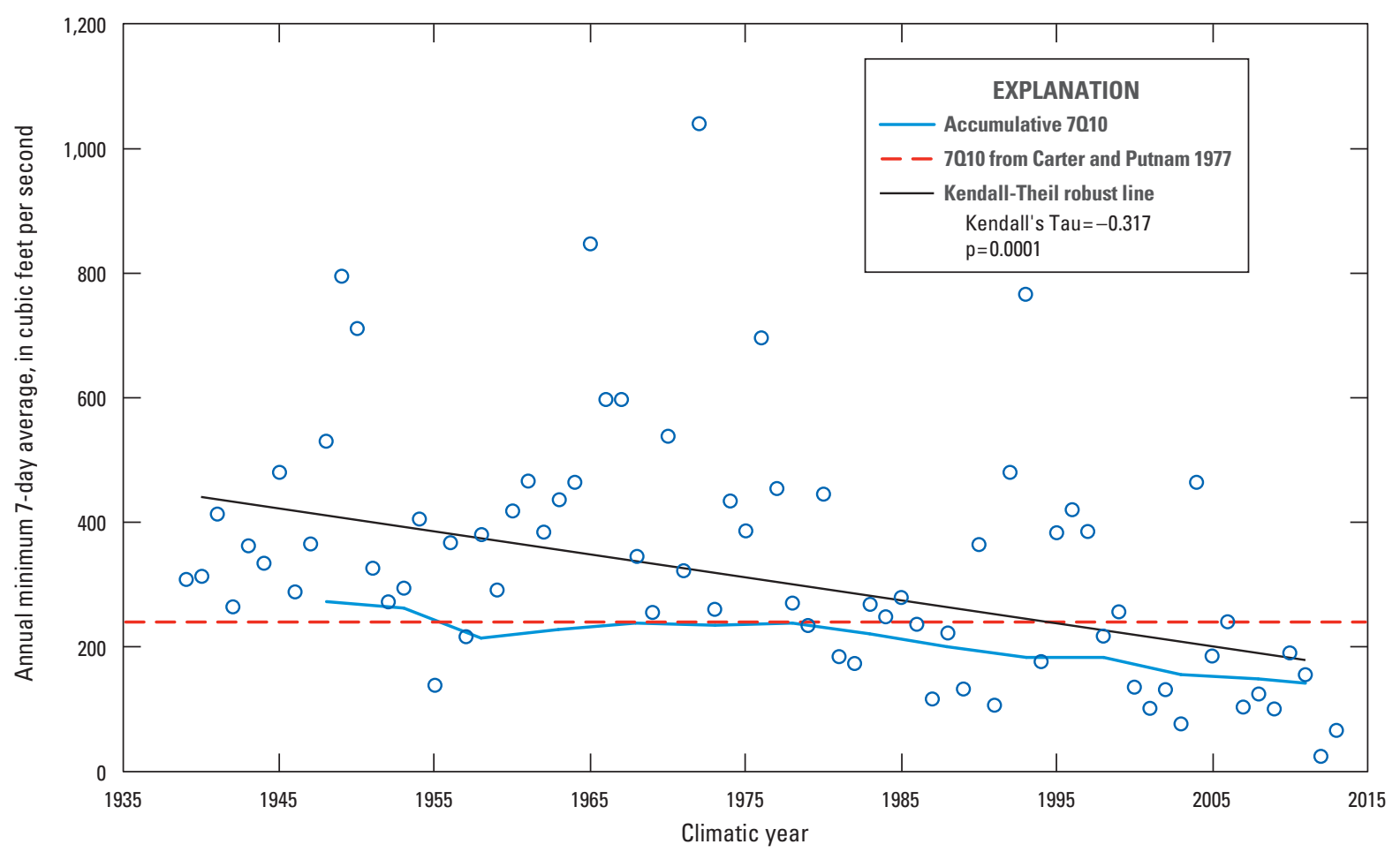

Figure 9. Annual minimum 7-day average flows and 7010 estimates at USGS streamgage 02202500 , Ogeechee River near Eden, Georgia.

$1 \mathrm{Q} 10$ and $7 \mathrm{Q} 10$ statistics were initially computed for the streamgage once 30 or more years of record were available at the beginning of the decade. For each subsequent decade, the annual and monthly $1 \mathrm{Q} 10$ and 7Q10 were computed by adding the 10 years of record from the previous decade. Table 6 shows a summary of the number of streamgages that show a decrease or increase in annual 7Q10 from the previous decade. Most of the streamgages showed a decline in the 7Q10 statistics for 1990, 2000, and 2010 because of the recent droughts in Georgia. Twenty four of the 39 streamgages had complete record from 1980 to 2010, and 23 these streamgages exhibited a decline in the $7 \mathrm{Q} 10$ statistic during this period that ranged from -6.3 to -76.2 percent, with a mean of -27.3 percent. No attempts were made in this study to adjust streamflow records or statistical analyses on the basis of trends in annual and monthly minimum 1-day and 7-day average flows.
Table 6. Summary of the number of streamgages with an increase or decrease in the annual 7010 statistics from the previous decade.

[7Q10, minimum 7-day average streamflow with a 10-year recurrence interval]

\begin{tabular}{ccc}
\hline \multirow{2}{*}{ Year } & \multicolumn{2}{c}{ Number of streamgages } \\
\cline { 2 - 3 } & $\begin{array}{c}\text { With a decrease in } \\
\text { the 7010 from the } \\
\text { previous decade }\end{array}$ & $\begin{array}{c}\text { With an increase in } \\
\text { the 7010 from the } \\
\text { previous decade }\end{array}$ \\
\hline 1970 & 0 & 3 \\
1980 & 4 & 13 \\
1990 & 22 & 2 \\
2000 & 22 & 9 \\
2010 & 38 & 1 \\
\hline
\end{tabular}




\section{Access to Updated Low-Flow Characteristics Through StreamStats Application}

StreamStats is a Web-based geographic information system (GIS) that provides users with access to an assortment of analytical tools that are useful for water-resources planning and management, and for engineering design applications, such as the design of bridges (Ries and others, 2008). StreamStats allows users to easily obtain streamflow statistics, basin characteristics, and other information for user-selected sites on streams. StreamStats users can choose locations of interest from an interactive map and obtain information for these locations. If a user selects the location of a USGS streamgage, the user will be provided with a list of previously published information for the streamgage. The monthly and annual 1Q10 and 7Q10 flow values in table 2 were added into StreamStatsDB, which is a database accessible to users through the StreamStats application. Complete instructions for using StreamStats are provided through links on the StreamStats Web site at http://water.usgs.gov/osw/streamstats/ index.html. The Web site also provides links to (1) information about general limitations of the application, (2) other State applications, (3) user instructions, (4) definitions of terms, (5) answers to frequently asked questions, (6) downloadable presentations and other technical information about the application, (7) information that can be accessed only by USGS employees, and (8) contact information.

\section{Summary}

To provide the Georgia Environmental Protection Division with tools for making future water-resources decisions, the U.S. Geological Survey (USGS) conducted a study to compute low-flow frequency statistics for selected streamgages in Georgia. The annual and monthly minimum 1- and 7-day average streamflows with the 10-year recurrence interval (1Q10 and 7Q10) statistics were computed for 197 continuous-record streamgages in Georgia. Streamgages used in the study included both active and discontinued stations with approved streamflow records having a minimum of 10 complete climatic years of record as of September 30, 2013. The 1Q10 and 7Q10 flow statistics were computed for 85 streamgages on unregulated streams with minimal diversions upstream, 43 streamgages on regulated streams, and 69 streamgages known, or considered, to be affected by varying degrees of diversions upstream. The statistics were computed using the USGS Surface-Water Statistics (SWSTAT) computer program version 5.0.
Kendall's tau nonparametric test was used to determine statistical significance of trends in the annual and monthly minimum 1-day and 7-day average flows for the 197 streamgages. Significant negative trends in the minimum annual 1-day and 7-day average streamflow were indicated for 77 of the 197 streamgages. Most of these significant negative trends are due to the period of record ending within the recent droughts in Georgia, particularly those streamgages with records through the 2013 water year. Records from long-term unregulated streamgages having 70 or more years of record indicate significant negative trends in the annual minimum 7-day average flow for central and southern Georgia. The watershed for one of these streamgages has experienced minimal human impact, thus indicating that the significant negative trends observed in the long-term streamgages may be influenced by changing climatological conditions. A trend analysis of the annual air temperature and precipitation totals for Georgia indicated no significant trends, however. A comprehensive analysis concerning the causes of the trends in annual and monthly minimum 1-day and 7-day average flows in central and southern Georgia is outside the scope of this investigation. Further study is needed to determine all of the causes, including both climatological and human impacts, of the significant negative trends in annual minimum 1-day and 7-day average flows in central and southern Georgia.

To assess the changes in the annual 1Q10 and 7Q10 statistics over time for long-term continuous streamgages with significant trends, the annual 1Q10 and 7Q10 statistics were computed on a decadal accumulated basis for 39 streamgages having 40 or more years of record that indicated a significant trend. Most of the streamgages showed a decline in the 7Q10 statistics for the decades of 1980, 1990, and 2000 because of the recent droughts in Georgia. Twenty four of the 39 streamgages had complete record from 1980 to 2010 and record for 23 of these streamgages exhibited a decline in the 7Q10 statistics during this period that ranged from -6.3 to -76.2 percent, with a mean of -27.3 percent. No attempts were made in this study to adjust streamflow records or statistical analyses on the basis of trends.

The monthly and annual $1 \mathrm{Q} 10$ and 7Q10 flow statistics for the entire period of record analyzed in the study are incorporated into the USGS StreamStatsDB, which is a database accessible to users through the recently released USGS StreamStats application for Georgia. StreamStats is a Web-based geographic information system that provides users with access to an assortment of analytical tools that are useful for water-resources planning and management, and for engineering design applications, such as the design of bridges. StreamStats allows users to easily obtain streamflow statistics, basin characteristics, and other information for user-selected streamgages. 


\section{References Cited}

Barbie, D.L., Wehmeyer, L.L., and May, J.E., 2012, Analysis of trends in selected streamflow statistics for the Concho River Basin, Texas, 1916-2009: U.S. Geological Survey Scientific Investigations Report 2012-5193, 15 p., accessed June 8, 2015, at http://pubs.usgs.gov/sir/2012/5193/.

Barber, N.L., and Stamey, T.C., 2000, Droughts in Georgia: U.S. Geological Survey Open-File Report 2000-380, $2 \mathrm{p}$. [Also available online at http://pubs.usgs.gov/of/ 2000/0380/.]

Carter, R.F., 1977, Low-flow characteristics of the upper Flint River, Georgia: U.S. Geological Survey Open-File Report 77-408, $10 \mathrm{p}$.

Carter, R.F., 1983, Effects of the drought of 1980-81 on streamflow and on groundwater levels in Georgia: U.S. Geological Survey Water-Resources Investigations Report 83-4158, 46 p.

Carter, R.F., and Fanning, J.D., 1982, Monthly low-flow characteristics of Georgia streams: U.S. Geological Survey Water-Resources Investigations Report 82-560, $81 \mathrm{p}$.

Carter, R.F., Hopkins, E.H., and Perlman, H., 1986, Low-flow profiles of the upper Ocmulgee and Flint Rivers in Georgia: U.S. Geological Survey Water-Resources Investigations Report 86-4176, 239 p.

Carter, R.F., Hopkins, E.H., and Perlman, H., 1988a, Lowflow profiles of the upper Savannah and Ogeechee Rivers and tributaries in Georgia: U.S. Geological Survey WaterResources Investigations Report 88-4047, 169 p.

Carter, R.F., Hopkins, E.H., and Perlman, H., 1988b, Lowflow profiles of the upper Oconee River and tributaries in Georgia: U.S. Geological Survey Water-Resources Investigations Report 88-4048, 136 p.

Carter, R.F., Hopkins, E.H., and Perlman, H., 1988c, Lowflow profiles of the Tennessee River tributaries in Georgia: U.S. Geological Survey Water-Resources Investigations Report 88-4049, 69 p.

Carter, R.F., Hopkins, E.H., and Perlman, H., 1988d, Lowflow profiles of the Tallapoosa River and tributaries in Georgia: U.S. Geological Survey Water-Resources Investigations Report 88-4050, 39 p.

Carter, R.F., Hopkins, E.H., and Perlman, H., 1989a, Lowflow profiles of the Coosa River and tributaries in Georgia: U.S. Geological Survey Water-Resources Investigations Report 89-4055, 217 p.
Carter, R.F., Hopkins, E.H., and Perlman, H., 1989b, Lowflow profiles of the upper Chattahoochee River tributaries in Georgia: U.S. Geological Survey Water-Resources Investigations Report 89-4056, 194 p.

Carter, R.F. and Putnam, S.A., 1978, Low-flow frequency of Georgia streams: U.S. Geological Survey Water-Resources Investigations Report 77-127, 104 p.

Cleveland, W.S., and Devlin, S.J., 1988, Locally-weighted regression-An approach to regression analysis by local fitting: Journal of the American Statistical Association, v. 83 , no. 403 , p. $596-610$.

Doheny, E.J., and Banks, W.S.L., 2010, Selected low-flow frequency statistics for continuous-record streamgage locations in Maryland, 2010: U.S. Geological Survey Open-File Report 2010-1310, 22 p., accessed July 23, 2015, at http://pubs.usgs.gov/of/2010/1310/.

Feaster, T.D., and Guimaraes, W.B., 2014, Low-flow frequency and flow duration of selected South Carolina streams in the Catawba-Wateree and Santee River Basins through March 2012: U.S. Geological Survey Open-File Report 2014-1113, 34 p., accessed July 14, 2015, at http://pubs.usgs.gov/of/2014/1113/.

Flynn, K.M., Hummel, P.R., Lumb, A.M., and Kittle, J.L., Jr., 1995, User's manual for ANNIE, Version 2, a computer program for interactive hydrologic data management: U.S. Geological Survey Water-Resources Investigations Report 95-4085, $211 \mathrm{p}$.

Fowler, K.K., and Wilson, J.T., 2015, Low-flow characteristics for selected streams in Indiana: U.S. Geological Survey Scientific Investigations Report 2014-5242, 353 p., accessed July 7, 2015, at http://pubs.usgs.gov/sir/2014/5242/.

Fry, J., Xian, G., Jin, S., Dewitz, J., Homer, C., Yang, L., Barnes, C., Herold, N., and Wickham, J., 2011, Completion of the 2006 National Land Cover Database for the conterminous United States: Photogrammetric Engineering and Remote Sensing Journal, v. 77, no. 9, p. 858-864.

Griffith, G.E., Omernik, J.M., Comstock, J.A., Schafale, M.P., McNab, W.H., Lenat, D.R., MacPherson, T.F., Glover, J.B., and Shelburne, V.B., 2002, Ecoregions of North Carolina and South Carolina: U.S. Geological Survey, map scale $1: 1,500,00$.

Helsel, D.R., and Hirsch, R.M., 1992, Statistical methods in water resources: New York, Elsevier, p. 326.

Hutchison, N.E., comp., 1975 (revised 1984), WATSTORE user's guide, Volume 1, National Water Data Storage and Retrieval System: U.S. Geological Survey Open-File Report 75-426. [Variously paged.] 
Kendall, M.G., 1938, A new measure of rank correlation: Biometrika, v. 30, no. 1-2, p. 81-93, accessed July 14, 2015, at http://www.jstor.org/stable/2332226.

Knaak, A.E., Frantz, E.R., and Peck, M.F., 2013, Extreme drought-Summary of hydrologic conditions in Georgia, 2011: U.S. Geological Survey Fact Sheet 2013-3002, 6 p. [Also available online at http://pubs.usgs.gov/fs/2013/3002/.]

Knaak, A.E., and Joiner, J.K., 2008, Hydrologic streamflow conditions for Georgia, 2007: U.S. Geological Survey Fact Sheet 2008-3099, 4 p. [Also available online at http://pubs.usgs.gov/fs/2008/3099/.]

Knaak, A.E., Joiner, J.K., and Peck, M.F., 2009, Summary of hydrologic conditions in Georgia, 2008: U.S. Geological Survey Fact Sheet 2009-3109, 6 p. [Also available online at http://pubs.usgs.gov/fs/2009/3109/.]

Knaak, A.E., and Peck, M.F., 2014, Extreme droughtSummary of hydrologic conditions in Georgia, 2012: U.S. Geological Survey Fact Sheet 2014-3028, 8 p. [Also available online at http://pubs.usgs.gov/fs/2014/3028/.]

Knaak, A.E., Pojunas, T.K., and Peck, M.F., 2010, Extreme drought to extreme floods: Summary of hydrologic conditions in Georgia, 2009: U.S. Geological Survey Fact Sheet 2010-3101, 6 p. [Also available online at http://pubs.usgs.gov/fs/2010/3101/.]

Lins, H.F., 2012, USGS Hydro-Climatic Data Network 2009 (HCDN-2009): U.S. Geological Survey Fact Sheet 20123047, 4 p., accessed July 14, 2015, at http://pubs.usgs.gov/ fs $/ 2012 / 3047 /$.

Lins, H.F., Hirsch, R.M., and Kiang, Julie, 2010, Water-The Nation's fundamental climate issue - A white paper on the U.S. Geological Survey role and capabilities: U.S. Geological Survey Circular 1347, 9 p, accessed July 27, 2015 at http://pubs.usgs.gov/circ/1347/.

Lumb, A.M., Kittle, J.L., Jr., and Flynn, K.M., 1990, User's manual for ANNIE, a computer program for interactive hydrologic analyses and data management: U.S. Geological Survey Water-Resources Investigations Report 89-4080, $236 \mathrm{p}$.

National Oceanic and Atmospheric Administration, 2015a, Climate of Georgia: National Oceanic and Atmospheric Administration, National Centers for Environmental Information Web site, accessed July 16, 2015, at http://www.ncdc.noaa.gov/climatenormals/clim60/ states/Clim_GA_01.pdf.

National Oceanic and Atmospheric Administration, 2015b, Climate at a glance: National Oceanic and Atmospheric Administration, National Centers for Environmental Information Web site, accessed August 16, 2015, at http://www.ncdc.noaa.gov/cag/time-series/us.
National Oceanic and Atmospheric Administration, 2015c, U.S. Climate Extremes Index: National Oceanic and Atmospheric Administration, National Centers for Environmental Information Web site, accessed August 16, 2015, at http://www.ncdc.noaa.gov/extremes/cei/graph.

Norton, P.A., Anderson, M.T., and Stamm, J.F., 2014, Trends in annual, seasonal, and monthly streamflow characteristics at 227 streamgages in the Missouri River watershed, water years 1960-2011: U.S. Geological Survey Scientific Investigations Report 2014-5053, 128 p. [Also available online at http://pubs.usgs.gov/sir/2014/5053/.]

Oki, D.S., 2004, Trends in streamflow characteristics at longterm gaging stations, Hawaii: U.S. Geological Survey Scientific Investigations Report 2004-5080, 116 p., accessed July 14, 2015, at http://pubs.usgs.gov/sir/2004/5080/.

Omernik, J.M., 1987, Ecoregions of the conterminous United States: Annals of the Association of American Geographers, v. 77, no. 1, p. 118-125, scale 1:7,500,000.

Ries, K.G., III, 2006, Selected streamflow statistics for streamgaging stations in Northeastern Maryland, 2006: U.S. Geological Survey Open-File Report 2006-1335, 16 p., accessed July 7, 2015, at http://pubs.usgs.gov/ of $/ 2006 / 1335 /$.

Ries III, K.G., Guthrie, J.G., Rea, A.H., Steeves, P.A., and Stewart, D.W., 2008, StreamStats-A water resources Web application: U.S. Geological Survey Fact Sheet 2008-3067, 6 p., accessed July 7, 2015 at http://pubs.usgs.gov/fs/ 2008/3067/.

Riggs, H.C., 1968, Frequency curves: U.S. Geological Survey Techniques of Water-Resources Investigations, book 4, chap. A2, 15 p.

Riggs, H.C., 1972, Low-flow investigations: U.S. Geological Survey Techniques of Water-Resources Investigations, book 4, chap. B1, $18 \mathrm{p}$.

Stamey, T.C., 1996, Streamflow characteristics at selected sites in southwestern Georgia, southeastern Alabama, and northwestern Florida, near Lake Seminole: U.S. Geological Survey Open-File Report 95-455, 11 p.

Stamey, T.C., 2001, Preliminary assessment of streamflow characteristics for selected streams at Fort Gordon, Georgia: U.S. Geological Survey Open-File Report 01-296, 5 p.

Stamey, T.C., 2011, 2010 update-Streamflow characteristics at selected sites in southwestern Georgia, southeastern Alabama, and northwestern Florida, near Lake Seminole: U.S. Geological Survey Open-File Report 2011-1278, 10 p., accessed July 14, 2015, at http://pubs.usgs.gov/ of/2011/1278/. 
Thomson, M.T., and Carter, R.F., 1963, Effect of a severe drought (1954) on streamflow in Georgia: Georgia Geological Survey Bulletin 73, 97 p.

U.S. Environmental Protection Agency, 2007, Ecoregions of the United States: U.S. Environmental Protection Agency Web site, accessed on July 24, 2015, at http:/www.epa.gov/ eco-research/ecoregions.

U.S. Environmental Protection Agency, 2015, Flow alteration in urban streams: U.S. Environmental Protection Agency Web site, accessed August 16, 2015, at http://www.epa.gov/ caddis/ssr_urb_hyd1.html.

U.S. Geological Survey, 2007, Facing tomorrow's challenges-U.S. Geological Survey science in the decade 2007-2017: U.S. Geological Survey Circular 1309, x + 70 p., accessed July 14, 2015, at http://pubs.usgs.gov/ circ/2007/1309/.

U.S. Geological Survey, 2009, National Streamflow Information Program (NSIP): U.S. Geological Survey Web site, accessed June 8, 2015, at http://water.usgs.gov/nsip/ history1.html.
U.S. Geological Survey, 2013, Cooperative Water ProgramPriority Activities for FY 14: U.S. Geological Survey Web site, accessed on August 21, 2015, at http://water.usgs.gov/ coop/about/CWP.science.priorities.pdf.

U.S. Geological Survey, 2014, USGS surface-water data for the Nation: U.S. Geological Survey National Water Information System, accessed April 3, 2014, at http://dx.doi.org/ 10.5066/F7P55KJN.

Weaver, J.C., 2015, Low-flow characteristics and flowduration statistics for selected USGS continuous-record streamgaging stations in North Carolina through 2012: U.S. Geological Survey Scientific Investigations Report 2015-5001, 89 p, accessed July 14, 2015, at http://pubs.usgs.gov/sir/2015/5001/. 


\section{Glossary}

climatic year The annual period from April 1 through March 31 used by the USGS for low-flow analyses at USGS continuousrecord streamgages. A climatic year is designated by the year in which the period begins. For example, the 2011 climatic year is from April 1, 2011, through March 31, 2012. The year begins and ends during the period of increased streamflow so that all streamflow during a single dry season is included in annual values for that year.

continuous-record streamgage A streamgage where continuous systematic observations of discharge are obtained.

drainage area The drainage area of a stream at a specified location is the area, measured in a horizontal plane, which is enclosed by a drainage divide.

partial-record streamgage A streamgage where periodic measurements are made during low-flow conditions.

record Unit value or daily mean streamflow data that are collected continuously from streamgage locations, electronically stored, published, and archived according to USGS protocols. recurrence interval As applied to low-flow statistics, the recurrence interval (sometimes called the return period) is based on the probability that the given event will be equal to or less than the estimated value in any given year. Thus, for the 7Q10, there is a 0.10 or 10 -percent probability that the annual minimum 7-day average flow in any 1 year will be less than the estimated $7 \mathrm{Q} 10$ value.

streamgage A site on a stream where continuous records of gage height are collected and for which streamflow records are computed.

water year The annual period from October 1 through September 30 that is used by the USGS for the collection and processing of streamflow records. The water year is designated by the year in which the period ends. For example, the 2012 water year is October 1, 2011, to September 30, 2012. 
Manuscript approved on March 25, 2016

Prepared by the USGS Science Publishing Network Raleigh Publishing Service Center

Edited by Michael Deacon

Illustrations and layout by Caryl J. Wipperfurth

For more information about this publication contact: Director, South Atlantic Water Science Center U.S. Geological Survey

720 Gracern Road

Columbia, SC 29210

http://www.usgs.gov/water/southatlantic/ 
